\title{
A Longitudinal Study of the Acquisition of Verbal Morphology in the EFL Classroom
}

\author{
ABSTRACT
}

This paper investigates the order of the acquisition of grammatical morphemes in the interlanguage of Croatian pupils of English as a foreign language (EFL). The order of acquisition was determined for nine grammatical morphemes. Additionally, the selected morphemes were combined to form the four verb tenses so as to determine the order of their emergence in the pupils' verb-morphology repertoire. The study was conducted on a corpus of 36 transcribed recordings of parts of classroom interaction. The pupils' speech production was elicited by various task-based activities. The suppliance of nine grammatical morphemes was investigated by means of obligatory occasion analysis (Brown 1973) which examined their obligatory and correct use. The obtained results revealed progress only in the acquisition of the present tense copula be. The emergence of verb tenses was partly identified due to the insufficient suppliance of grammatical morphemes in the pupils' speech production.

Keywords: order of acquisition; grammatical morphemes; verb tenses; task-based activities; obligatory context

\section{Longitudinalna raziskava usvajanja glagolskega oblikoslovja pri učenju angleščine kot tujega jezika}

\author{
POVZETEK
}

V prispevku predstavljamo raziskavo, ki ugotavlja, v kakšnem vrstnem redu hrvaški učenci angleščine kot tujega jezika v vmesnem jeziku usvajajo devet slovničnih morfemov. Dodatno smo izbrane morpheme opazovali tudi pri tvorjenju štirih glagolskih časov, da bi ugotovili, v kakšnem vrstnem redu in obsegu se pojavljajo pri usvajanju glagolskega oblikoslovja. Za raziskavo smo uporabili 36 transkripcij zvočnih posnetkov delov razrednih interakcij. Govorne odzive učencev smo spodbudili s pomočjo na nalogah zasnovanih dejavnosti. Uporabo/pojavnost devetih slovničnih morfemov smo proučevali na osnovi obvezne situacijske analize (Brown 1973), s katero smo raziskali obvezno in pravilno rabo morfemov. Rezultati dokazujejo učenčev napredek samo pri usvajanju sedanjika veznega glagola biti. Zaradi pomanjkljive rabe glagolskih morfemov v govoru učencev je bilo tvorjenje glagolskih časov le delno dokazano.

Ključne besede: vrstni red usvajanja; slovnični morfemi; glagolski časi; na nalogah temelječe dejavnosti; obvezno sobesedilo 


\section{A Longitudinal Study of the Acquisition of Verbal Morphology in the EFL Classroom}

\section{Introduction}

There has always been a certain amount of curiosity regarding how people acquire a second language (L2). Research in first language (L1) acquisition that sought to investigate the acquisition of grammatical morphemes provided the impetus for second language studies commonly referred to as morpheme studies. These studies were carried out to investigate whether there was a universal order of acquisition and whether it was identical to or different from that found in L1 acquisition. Based on the findings of grammatical morpheme research, Dulay and Burt (1980, 325) claimed that the discovery of a common acquisition sequence in an L2 was "surely one of the most exciting and significant outcomes of the last decade of second language research". Although the acquisition of morphological features was a starting point for numerous morpheme studies, more recent studies in the field of second language acquisition (SLA) investigate the tense-aspect system and the emergence of verbal morphology. This paper attempts to provide new insights into the order of acquisition of both grammatical morphemes and verb tenses in EFL classroom settings in Croatia. The first part of the paper provides a theoretical framework for the study, which is followed by the results of the data analyses.

\section{Literature Review}

\subsection{Morpheme Order Studies}

Much of the early morpheme studies of the 1970s focused on the order of the acquisition of grammatical morphemes. These studies were both cross-sectional and longitudinal, although the former prevailed. The studies employed obligatory occasion analysis as a tool for investigating the accuracy with which learners of L2 English performed a number of grammatical morphemes.

It was Roger Brown (1973) who first developed this method and applied it in his longitudinal study of $\mathrm{L} 1$ acquisition. He examined the emergence of 14 morphemes in three children's acquisition of English to see how many times per recording each morpheme occurred in obligatory contexts, i.e., occasions on which a native speaker is obliged to use a particular morpheme. When a morpheme was supplied in $90 \%$ or more of these obligatory contexts in three successive recordings, the child was regarded as having acquired that morpheme. Brown found a remarkable amount of invariance in the orders of acquisition among the three children.

Dulay and Burt (1973), adopting Brown's procedure and a subset of his morphemes, attempted to find such an order for Spanish children learning English as an L2. Each obligatory context for a morpheme was scored on a three-point scale: a missing morpheme counted as zero ("She's dance."), a misformed morpheme as 0.5 ("She's dances.") and a correct morpheme as one point ("She's dancing."). Their results showed that three groups of children acquired eight morphemes in a common order despite differences in hours of exposure to the L2 and different language backgrounds. Expanding their research, Dulay and Burt $(1974,49)$ concluded that the L1 has no impact on the order of acquisition due to a "strikingly similar" order for both Spanish and Chinese children. 
Their findings led to many other studies which replicated the basic design of their research while varying the conditions and changing the number of morphemes studied. Bailey, Madden and Krashen (1974) found a common acquisition order for both Spanish and non-Spanish adults which differed from the L1 order. The acquisition order Hakuta (1974) obtained for a Japanese girl, however, did not match the orders obtained by Dulay and Burt (1973, 1974). LarsenFreeman (1975) used different elicitation tasks which led her to conclude that the learners' L1s made little difference to the acquisition orders; nevertheless, some differences in the orders occurred in speaking and writing tasks. She also concluded that language instruction and the amount of exposure to English do not have much effect on morpheme orderings.

Although the popularity of morpheme studies declined in the 1980s, there have been a few recent studies which inquired into other aspects of acquisition, along with the acquisition of grammatical morphemes. Unlike the early morpheme studies, these studies analysed the influence of the learning environment (Makino 1980; Pica 1983), the impact of age (Pak 1987), the use of learning strategies (Billings 1999) or, for example, the influence of affective factors (Wang 2000).

Morpheme studies have been subject to considerable criticism. The identification of obligatory occasions seemed to be disputable due to the problem of counting repetitions which could be counted as either one obligatory occasion or two for a certain morpheme (Ellis and Barkhuizen 2005). Furthermore, the research has been restricted to a small set of morphemes without paying attention to allomorphic variation. A more serious criticism was that the morphemes brought together disparate aspects of grammar such as features of the verb phrase (e.g., past regular, past irregular, progressive -ing, third person singular $-s$ ) and features of the noun phrase (e.g., plural $-s$, possessive $-s$, articles) (Cook 1993). An additional flaw of morpheme studies was found in the level of the accurate suppliance of grammatical morphemes, ranging from $60 \%$ to $80 \%$ or even 90\%, depending on the researcher (Lakshmanan and Selinker 2001). Finally, it has also been claimed that the accurate suppliance of a morpheme in an obligatory context "does not necessarily mean the learner knows its function(s)" (Long and Sato 1984, 260). Contrary to what some critics have alleged, far too many studies have provided concrete evidence for commonalities in the acquisition orders of grammatical morphemes regardless of a learner's native language background, age, learning conditions, amount of exposure to English or type of elicitation task (Ortega 2009).

\subsection{Studies of Tense-Aspect Acquisition}

Although early morpheme studies reflected the interest of SLA in determining acquisition orders, the acquisition of morphological features in terms of the tense-aspect system has been intensively studied in more recent years through meaning-oriented and form-oriented approaches. The meaning-oriented approach was larger in scope since it also included pragmatic and lexical means of temporal expression. The form-oriented approach, which concentrated exclusively on verbal morphology, investigated acquisition sequences, the influence of the lexical aspect and the influence of discourse structure (Bardovi-Harlig 2000).

Form-oriented studies of the acquisition of verbal morphology differed in many ways from the earlier morpheme studies. First, they examined the tense-aspect system in its own right, thus avoiding the criticism of morpheme studies, which combined disparate morphological features. Second, they were rather more longitudinal than cross-sectional in design and third, acquisition was defined in terms of emergence rather than approximation to target-language accuracy (Ellis 2008). 
Research of emergence orders in the acquisition of verbal morphology related to the expression of the past has been most widely investigated by Bardovi-Harlig (1997, 2000). According to Bardovi-Harlig (2000), four general principles in the acquisition of tense-aspect morphology have been established. First, the development of temporal expression is slow and gradual and second, form often precedes function. Third, irregular morphology precedes regular morphology and fourth, when acquiring compound verb tenses, a verb with a verbal suffix is acquired prior to an auxiliary verb.

Even though studies of the acquisition of tense-aspect morphology prevail, inquiry into learners' use of morphemes via obligatory occasion analysis still has much to offer SLA. The information it provides serves as a basis for testing the influence of different variables on the morpheme order such as, for instance, the number of morphemes, the design of the study, the methodology applied or the learners' L1. Therefore, this paper attempts to expand morpheme order studies by implementing a longitudinal approach to examine the order of the acquisition of grammatical morphemes and verb tenses in the interlanguage of Croatian L2 pupils of English.

\section{Aims of the Study}

This study seeks to answer the following research questions:

RQ1: What is the suppliance of grammatical morphemes regarding their obligatory and correct use, and how is it distributed in the speech production of Croatian elementary school pupils over the three-year period of learning?

RQ2: What is the order of the acquisition of grammatical morphemes and verb tenses obtained by Croatian elementary school pupils in each year of learning? Are there any differences among acquisition orders over the three-year period of learning?

RQ3: Is there any improvement in the acquisition of grammatical morphemes and verb tenses over the three-year period of learning?

RQ4: Which of the two grammatical morphemes, past regular or past irregular, is acquired earlier?

RQ5: When acquiring compound verb tenses, which of the two grammatical morphemes, auxiliary verb or verbal suffix, is acquired earlier?

\section{Methodology}

\subsection{Participants}

The participants were 20 Croatian-speaking pupils from an elementary school in the SplitDalmatia County. The same group of pupils took part in this study over the three-year period of data collection, i.e., in Grade 6, Grade 7 and Grade 8. Sixth grade elementary school pupils participating in the first year of research (2008/2009) were aged 11-12, seventh grade elementary school pupils in the second year of research (2009/2010) were aged 12-13, while eighth grade elementary school pupils in the third year of research (2010/2011) were aged 1314. All the pupils started their EFL studies in the first grade, since English is a compulsory school 
subject within the Croatian education context. ${ }^{1}$ According to the national curriculum (Ministry of Science and Education of the Republic of Croatia 2011), eighth grade pupils completing elementary education are expected to reach the CEFR A2 level. ${ }^{2}$

Since the author was the pupils' former English language teacher and therefore knew both the pupils and their parents rather well, the parents most willingly gave their oral consent for this research. Furthermore, the school headmaster, the parents and the children were all informed about the aims of the research and the data collection procedure. ${ }^{3}$

\subsection{Data Collection}

The data collection included 36 tape-recorded samples (15 in both the first and the second years of research and 6 in the third year of research) of parts of the EFL classroom interaction. The average length of each recording was 15 minutes. The recordings were made by the teacher, while the author took notes about the pupils' verbal behaviour during the recording sessions. As a result, accurate recordings without data loss were obtained. All of the data were transcribed, and in addition, checked against the tape recordings. The transcription of the audio samples was conducted by the author, who designed her own notation symbols following suggestions from transcription literature (DuBois 1991; Edwards 2001; Edwards and Lampert 1993). Data were collected through various task-based activities (Harmer 1999; Ur 1999; Thornbury 2005) designed to elicit the use of grammatical morphemes.

\subsubsection{Selection and Coding}

The grammatical morphemes selected in this study were those forming the following verb tenses: simple present, present continuous, simple past and present perfect. The simple present comprised the third person singular $(-s)$, the present continuous comprised the auxiliary verb be and the progressive (-ing), the simple past comprised both the past regular and the past irregular and finally, the present perfect comprised the auxiliary verb have and the past participle (-en).

Apart from the seven chosen morphemes, two more were selected: the present tense copula be (am, are, is) and the past tense copula be (was, were). These morphemes were added since the examples found in the corpus, as in the question-answer exchange Are there a TV in your bedroom? No, it isn't or as in He was be at home, drew attention to the difficulties in the pupils' speech production caused by their use.

The nine morphemes included in this study were those that had been analysed in previous morpheme order studies belonging to both the early and more recent period in SLA. The only exception was made regarding the acquisition of morphemes constituting the present perfect since their acquisition was partly investigated in some of the recent studies (e.g., Bardovi-Harlig 1997, 2000).

For more information regarding the Croatian education system, visit the website of the Croatian Ministry of Science, Education and Sport, http://public.mzos.hr/Default.aspx?sec=2501, accessed 13 April 2017.

2 A2 level global descriptor: "Can understand sentences and frequently used expressions related to areas of most immediate relevance (e.g. very basic personal and family information, shopping, local geography, employment). Can communicate in simple and routine tasks requiring a simple and direct exchange of information on familiar and routine matters. Can describe in simple terms aspects of his/her background, immediate environment and matters in areas of immediate need." (Council of Europe 2001, 24).

3 According to the Ethical Code for Research with Children (Ajduković and Kolesarić 2003), either oral or written parental consent is required for children under the age of 14 . 
The use of grammatical morphemes is illustrated by the following examples from the corpus:

- third person singular $(-s)$

He gets up er seven oclock in the morning. (Grade 6)

- auxiliary verb be

What is the teacher doing now? (Grade 6)

- progressive (-ing)

My grandmother is sleeping. (Grade 6)

- past regular (-ed)

I think ... I er ... ruined her clothes or something like that. (Grade 7)

- past irregular

Then ... he went to ... hospital. (Grade 7)

- auxiliary verb have

I have never been in Dubrovnik. (Grade 8)

- past participle (-en)

I want to go somewhere exotic like China ... Peru. I have never been nowhere like that. (Grade 8)

- present tense copula be (am, are, is)

My friends er are never er ... more important than my family because my family in life is on er first ... place. (Grade 7)

- $\quad$ past tense copula be (was, were)

Because it was really great and er it ... was funny and we were all together. (Grade 8)

The grammatical morphemes in this study were examined in obligatory contexts (Brown 1973). However, they were not scored according to the three-point scale scoring procedure (Dulay and Burt 1973). The idea of modifying the research method derived from a suggestion by LarsenFreeman (1975) and Bardovi-Harlig (2000), who encouraged changes in the research design to verify the validity of the previous morpheme order findings.

The use of morphemes was examined regarding their obligatory and correct suppliance. When a morpheme was supplied in a context which required the presence of a particular morpheme, its use was considered obligatory. When a morpheme was supplied in its correct grammatical form and context, its use was considered correct. The suppliance of obligatory and correct use was coded for each of the nine morphemes. The obligatory use of a particular morpheme was coded by counting all the obligatory occasions for that morpheme. The correct use was coded similarly, i.e., by counting all the correct instances for the same morpheme. If a pupil said After school we went in a park and then... we buy er ice-cream, the obligatory occasions for the use of the irregular past were created twice (went, bought), whilst the correct use of the desired morpheme was produced only once (went). Therefore, the suppliance of the irregular past was coded as two obligatory uses and one correct use.

Coding of grammatical morphemes according to their obligatory and correct use was performed in every transcribed tape recording for each pupil across Grade 6, Grade 7 and Grade 8. The data were coded in a slightly modified version of the coding table originally developed by LarsenFreeman (1975). 


\subsection{Data Analysis}

Having coded the morphemes, the data were transferred to MS-Excel tables for further analysis. Statistical analyses of the obtained data were conducted using the SPSS programme package for Windows 17.0. This section includes data analysis procedures for each of the research questions.

The suppliance of grammatical morphemes (RQ1) was analysed with regard to the total number of their obligatory and correct uses. The total number of obligatory uses was identified as the sum of all coded obligatory occasions for a particular morpheme and the total number of correct uses as the sum of all coded correct instances for the same morpheme. The total number of obligatory and correct uses was determined for each of the nine morphemes in all the transcribed tape recordings across Grade 6, Grade 7 and Grade 8.

The order of the acquisition of grammatical morphemes (the first part of RQ2) was determined by the group score method (Dulay and Burt 1974). The group score for a particular morpheme was obtained by computing a ratio of the total number of its correct uses to the total number of its obligatory uses. The resulting quotient was then multiplied by 100 and expressed as a percentage. Once group scores were computed for each of the nine morphemes, the morphemes were then ranked according to decreasing group score to yield a sequence of acquisition. The advantage of this method, as stated by Dulay and Burt (1974), is that even pupils who produce just one obligatory occasion for a morpheme can be included in the group score. The potential danger of this method is that the contribution of only one obligatory occasion does not necessarily indicate that the pupil has actually acquired the specific morpheme. Thus, the group means method (Dulay and Burt 1974) was applied in order to minimize that danger. According to this method, all pupils with fewer than three obligatory occasions for the morpheme in question were eliminated from the sample. Mean functor scores were computed for each of the nine morphemes and the acquisition sequence was obtained by ranking the morphemes according to decreasing mean functor score.

The order of the acquisition of verb tenses (the first part of RQ2) was determined by grouping the data on obligatory and correct uses of the nine morphemes around the four tenses. The simple present included instances of obligatory and correct uses for the third person singular $(-s)$ and the present tense copula be, while the present continuous implicated the suppliance of the auxiliary verb be and the progressive (-ing). The simple past comprised the suppliance of the past regular, the past irregular and the past tense copula be and, finally, the present perfect incorporated the use of the auxiliary verb have and the past participle (-en). The group score method (Dulay and Burt 1974) was the only method used in establishing the order of the acquisition of verb tenses since it was the primary method of speech analysis in this study. The acquisition sequence was obtained by ranking the verb tenses in decreasing order of accuracy.

The acquisition sequences of the grammatical morphemes obtained by both methods across Grade 6, Grade 7 and Grade 8 were compared using Spearman rank order correlations to verify the stability and reliability of the obtained data. The same type of correlation was used to compare the sequences of morphemes and verb tenses obtained only by the group score method across Grade 6, Grade 7 and Grade 8 to determine if there were any differences among acquisition sequences during the three years of learning (the second part of RQ2).

Improvement in the acquisition of grammatical morphemes and verb tenses (RQ3) was analysed with regard to the significance of differences in their acquisition across Grade 6, Grade 7 and Grade 8. To determine the significance of the differences over the three-year period of learning, 
an average accuracy score was calculated. The average accuracy score could be calculated only for the pupils who exhibited instances of correct use for the morphemes and verb tenses in their speech production. For each of the nine morphemes, the average accuracy score was computed as a ratio of the portion of correct uses for a particular morpheme supplied to the portion of obligatory uses for that morpheme. The same procedure was used to determine the average accuracy score for each of the four verb tenses. The average accuracy score for both morphemes and verb tenses was established by Friedman's nonparametric test. In situations where the average accuracy score for the morphemes and verb tenses across Grade 6, Grade 7 and Grade 8 could not be calculated, Wilcoxon's nonparametric test was used for Grade 6 and Grade 7.

To determine which of the two morphemes, past regular or past irregular, Croatian elementary school pupils acquire earlier (RQ4), the data on the suppliance of their correct use along with the orders of their acquisition based on the group score method were analysed. When analysing which of the morphemes constituting the present continuous and the present perfect, i.e., the auxiliary verb or verbal suffix, Croatian elementary school pupils acquire first (RQ5), the data regarding the suppliance of their correct use and their acquisition orders based on the group score method were studied.

\section{Results}

The following sections present the research results. The obtained results are displayed according to the research questions.

\subsection{Results on the Suppliance and the Distribution of Grammatical Morphemes regarding Their Obligatory and Correct Uses}

This subsection reveals the findings addressing RQ1. The suppliance of grammatical morphemes along with their distribution in obligatory and correct uses was examined across Grade 6, Grade 7 and Grade 8 .

TABLE 1. Overall suppliance of grammatical morphemes across Grade 6, Grade 7 and Grade 8.

\begin{tabular}{|c|c|c|c|}
\hline \multirow{2}{*}{ Grade } & \multicolumn{2}{|c|}{$\begin{array}{c}\text { Suppliance of } \\
\text { grammatical morphemes }\end{array}$} & \multirow{2}{*}{ TOTAL } \\
\cline { 2 - 3 } & $\begin{array}{c}\text { Obligatory use } \\
(\%)\end{array}$ & $\begin{array}{c}\text { Correct use } \\
(\%)\end{array}$ & \\
\hline \multirow{2}{*}{6} & 1495 & 1060 & 2555 \\
& $(59 \%)$ & $(41 \%)$ & $(100 \%)$ \\
\hline \multirow{2}{*}{7} & 1800 & 1355 & 3155 \\
& $(57 \%)$ & $(43 \%)$ & 780 \\
\hline \multirow{2}{*}{8} & 455 & 325 & $(100 \%)$ \\
\hline
\end{tabular}

The results in Table 1 show that obligatory and correct uses of the morphemes were almost equally supplied by the same group of pupils during the three years of learning. Higher suppliance in the obligatory use of the morphemes was provided by Grade 6 pupils when compared to Grade 7 and Grade 8 pupils. Grade 6 pupils showed 2\% more suppliance in obligatory use than Grade 7 pupils and 1\% more suppliance than Grade 8 pupils. However, the correct use of the morphemes 
by Grade 7 pupils was supplied 2\% more in comparison to Grade 6 pupils and 1\% more in comparison to Grade 8 pupils. Despite the differences in obligatory use across Grade 6, Grade 7 and Grade 8, it can be claimed that task-based activities promote speech production, as the use of grammatical morphemes in obligatory contexts reached approximately $60 \%$. These activities, according to Ur (1999), foster target language production among the majority of pupils by being highly motivating and enjoyable.

TABLE 2. Distribution of obligatory and correct suppliance of grammatical morphemes across Grade 6, Grade 7 and Grade 8.

\begin{tabular}{|c|c|c|c|c|c|c|}
\hline \multirow{3}{*}{$\begin{array}{l}\text { Grammatical } \\
\text { morpheme }\end{array}$} & \multicolumn{6}{|c|}{ Grade } \\
\hline & \multicolumn{2}{|c|}{6} & \multicolumn{2}{|c|}{7} & \multicolumn{2}{|c|}{8} \\
\hline & $\begin{array}{c}\text { obligatory } \\
\text { use (\%) }\end{array}$ & $\begin{array}{l}\text { correct } \\
\text { use (\%) }\end{array}$ & $\begin{array}{c}\text { obligatory } \\
\text { use (\%) }\end{array}$ & $\begin{array}{l}\text { correct } \\
\text { use (\%) }\end{array}$ & $\begin{array}{c}\text { obligatory } \\
\text { use (\%) }\end{array}$ & $\begin{array}{l}\text { correct } \\
\text { use (\%) }\end{array}$ \\
\hline$-s$ & $\begin{array}{c}307 \\
(21 \%)\end{array}$ & $\begin{array}{c}155 \\
(15 \%)\end{array}$ & $\begin{array}{l}139 \\
(8 \%)\end{array}$ & $\begin{array}{c}65 \\
(5 \%)\end{array}$ & $\begin{array}{c}27 \\
(6 \%)\end{array}$ & $\begin{array}{c}10 \\
(3 \%)\end{array}$ \\
\hline $\begin{array}{l}\text { auxiliary } \\
\text { verb be }\end{array}$ & $\begin{array}{c}124 \\
(8 \%)\end{array}$ & $\begin{array}{c}88 \\
(8 \%)\end{array}$ & $\begin{array}{l}121 \\
(7 \%)\end{array}$ & $\begin{array}{c}97 \\
(7 \%)\end{array}$ & $\begin{array}{c}0 \\
(0 \%)\end{array}$ & $\begin{array}{c}0 \\
(0 \%)\end{array}$ \\
\hline -ing & $\begin{array}{c}124 \\
(8 \%)\end{array}$ & $\begin{array}{c}124 \\
(10 \%)\end{array}$ & $\begin{array}{c}121 \\
(7 \%)\end{array}$ & $\begin{array}{c}121 \\
(8 \%)\end{array}$ & $\begin{array}{c}0 \\
(0 \%)\end{array}$ & $\begin{array}{c}0 \\
(0 \%)\end{array}$ \\
\hline $\begin{array}{l}\text { past } \\
\text { regular }(-e d)\end{array}$ & $\begin{array}{l}128 \\
(9 \%)\end{array}$ & $\begin{array}{c}71 \\
(7 \%)\end{array}$ & $\begin{array}{l}156 \\
(9 \%)\end{array}$ & $\begin{array}{c}70 \\
(5 \%)\end{array}$ & $\begin{array}{c}55 \\
(12 \%)\end{array}$ & $\begin{array}{c}27 \\
(8 \%)\end{array}$ \\
\hline $\begin{array}{l}\text { past } \\
\text { irregular }\end{array}$ & $\begin{array}{c}288 \\
(19 \%)\end{array}$ & $\begin{array}{c}165 \\
(16 \%)\end{array}$ & $\begin{array}{c}426 \\
(24 \%)\end{array}$ & $\begin{array}{c}258 \\
(19 \%)\end{array}$ & $\begin{array}{c}167 \\
(37 \%)\end{array}$ & $\begin{array}{c}103 \\
(32 \%)\end{array}$ \\
\hline $\begin{array}{l}\text { auxiliary } \\
\text { verb have }\end{array}$ & $\begin{array}{c}0 \\
(0 \%)\end{array}$ & $\begin{array}{c}0 \\
(0 \%)\end{array}$ & $\begin{array}{c}0 \\
(0 \%)\end{array}$ & $\begin{array}{c}0 \\
(0 \%)\end{array}$ & $\begin{array}{c}0 \\
(0 \%)\end{array}$ & $\begin{array}{c}0 \\
(0 \%)\end{array}$ \\
\hline$-e n$ & $\begin{array}{c}0 \\
(0 \%)\end{array}$ & $\begin{array}{c}0 \\
(0 \%)\end{array}$ & $\begin{array}{c}22 \\
(1 \%)\end{array}$ & $\begin{array}{c}7 \\
(1 \%)\end{array}$ & $\begin{array}{c}0 \\
(0 \%)\end{array}$ & $\begin{array}{c}0 \\
(0 \%)\end{array}$ \\
\hline $\begin{array}{l}\text { be } \\
\text { (am, are, is) }\end{array}$ & $\begin{array}{c}347 \\
(23 \%)\end{array}$ & $\begin{array}{c}331 \\
(31 \%)\end{array}$ & $\begin{array}{c}638 \\
(35 \%)\end{array}$ & $\begin{array}{c}627 \\
(46 \%)\end{array}$ & $\begin{array}{c}90 \\
(20 \%)\end{array}$ & $\begin{array}{c}90 \\
(28 \%)\end{array}$ \\
\hline $\begin{array}{l}\text { be } \\
\text { (was, were) }\end{array}$ & $\begin{array}{c}177 \\
(12 \%)\end{array}$ & $\begin{array}{c}148 \\
(14 \%)\end{array}$ & $\begin{array}{c}177 \\
(10 \%)\end{array}$ & $\begin{array}{c}129 \\
(10 \%)\end{array}$ & $\begin{array}{c}116 \\
(25 \%)\end{array}$ & $\begin{array}{c}95 \\
(29 \%)\end{array}$ \\
\hline
\end{tabular}

Although Table 2 presents the results on the distribution of obligatory and correct suppliance of morphemes across Grade 6, Grade 7 and Grade 8 (RQ1), the focus is entirely on the distribution of their correct suppliance. This is due to the inevitable influence of numerous factors such as the type, presence or duration of a particular communitive activity, and also the number of pupils included in the speech production causing variability in the obligatory use of grammatical morphemes under study, making it more difficult to analyse. The influence of these factors will be discussed later. 
From Table 2 it is apparent that the two most frequently supplied morphemes with regard to their correct use across Grade 6, Grade 7 and Grade 8 are the present tense copula be and the past irregular. The copula be (am, are, is) accounted for $31 \%$ of correct suppliance in Grade 6, which, quite expectedly, rose to $46 \%$ the following year (Grade 7) and decreased by $18 \%$ in the last year of learning (Grade 8). Unlike all other morphemes, the past irregular is the only morpheme which underwent an increase in the suppliance of its correct use over the three-year period of learning. Grade 7 pupils displayed an increase of 3\% in comparison to Grade 6 pupils (16\% in Grade 6 and 19\% in Grade 7). A much higher increase in the correct suppliance of the past irregular appeared among Grade 8 pupils (32\%) in comparison to Grade 6 and Grade 7 pupils.

The correct use of the past tense copula be and the past regular showed a similar pattern of suppliance. In other words, the suppliance of these morphemes falls in Grade 7 and then rises again in Grade 8. Surprisingly, Grade 6 pupils most frequently supplied the correct use of the third person singular $(-s)$ over the three-year period of learning. A sharp decrease in the suppliance of the same morpheme was demonstrated by both Grade 7 and Grade 8 pupils. In Grade 7, the correct suppliance of this morpheme falls to 5\%, with a dramatic decline to just 3\% in Grade 8 .

The correct use of the morphemes comprising compound verb tenses (the present continuous and the present perfect) was only partially, if at all, supplied during the three years of learning. Although the suppliance of both morphemes constituting the present continuous slightly decreased in Grade 7, their use was entirely excluded from speech production in Grade 8. Pupils across Grade 6, Grade 7 and Grade 8 showed no suppliance of the morphemes forming the present perfect. The only exception was the correct use of the past participle which was $1 \%$ in Grade 7. The absence of the two morphemes constituting this tense is not surprising since the present perfect is not introduced to pupils in Grade 6. The exception in the use of the past participle could be accounted for by incorrect coding since the past participle and the past irregular, in most cases, have the same form.

Having examined the distribution of grammatical morphemes across Grade 6, Grade 7 and Grade 8 , it remains for us to address whether the more correct suppliance in the use of morphemes is a prerequisite for their earlier acquisition. To answer this, the order of acquisition of grammatical morphemes was analysed.

\subsection{Results on the Acquisition Orders of Grammatical Morphemes and Verb Tenses}

The first part of this subsection conveys the results addressing the first part of RQ2, thus initially exhibiting the acquisition orders of the grammatical morphemes followed by the acquisition orders of the verb tenses obtained in Grade 6, Grade 7 and Grade 8. The second part of this subsection discloses the results related to the second part of RQ2.

It can be observed in Table 3 that the present tense copula $b e$ and the past tense copula $b e$ were the first acquired morphemes in Grade 6, thus showing the highest accuracy scores $(95.4 \%$ for the present tense copula be, $83.6 \%$ for the past tense copula be). The progressive (-ing) was ranked in third position with an $82.3 \%$ accuracy score, while the auxiliary verb be, with an accuracy score of $71 \%$, was in fourth position. Also, the progressive (-ing) was higher in rank when compared to the third person singular $(-s)$, which was the last morpheme acquired with an accuracy score of $50.5 \%$. It seems that the past irregular was acquired earlier than the 
TABLE 3. Order of acquisition of grammatical morphemes in Grade 6.

\begin{tabular}{|l|c|c|c|c|}
\hline $\begin{array}{l}\text { Grammatical Method / Rank } \\
\text { morpheme }\end{array}$ & $\begin{array}{c}\text { Group means } \\
\text { method } \\
(\%)\end{array}$ & Rank & $\begin{array}{c}\text { Group score } \\
\text { method } \\
(\%)\end{array}$ & Rank \\
\hline$-\boldsymbol{s}$ & 45.3 & 7 & 50.5 & 7 \\
\hline auxiliary verb be & 63.2 & $\mathbf{4}$ & 71.0 & $\mathbf{4}$ \\
\hline -ing & 79.5 & $\mathbf{3}$ & 82.3 & $\mathbf{3}$ \\
\hline past regular (-ed) & 58.4 & $\mathbf{5}$ & 55.5 & $\mathbf{6}$ \\
\hline past irregular & 55.7 & $\mathbf{6}$ & 57.3 & $\mathbf{5}$ \\
\hline auxiliary verb have & & & & \\
\hline past participle (-en) & & & & $\mathbf{1}$ \\
\hline be (am, are, is) & 91.6 & $\mathbf{1}$ & 95.4 & $\mathbf{2}$ \\
\hline be (was, were) & 82.2 & $\mathbf{2}$ & 83.6 & \\
\hline
\end{tabular}

$\mathrm{r}_{\mathrm{gs,gm}} 6=0.96 ; \mathrm{p}<.05, \mathrm{p}<.01$

past regular, although these morphemes displayed a relatively similar level of accuracy differing by only $1.8 \%$ ( $57.3 \%$ for the past irregular, $55.5 \%$ for the past regular). To conclude, the acquisition sequence by Grade 6 pupils shows the following order: present tense copula be, past tense copula be, progressive (-ing), auxiliary verb be, past irregular, past regular and third person singular $(-s)$.

TABLE 4. Order of acquisition of grammatical morphemes in Grade 7.

\begin{tabular}{|l|c|c|c|c|}
\hline $\begin{array}{l}\text { Grammatical Method / Rank } \\
\text { morpheme }\end{array}$ & $\begin{array}{c}\text { Group means } \\
\text { method } \\
(\%)\end{array}$ & Rank & $\begin{array}{c}\text { Group score } \\
\text { method } \\
(\%)\end{array}$ & Rank \\
\hline$-\boldsymbol{s}$ & 47.4 & $\mathbf{6}$ & 46.8 & $\mathbf{6}$ \\
\hline auxiliary verb $\boldsymbol{b e}$ & 73.1 & $\mathbf{3}$ & 80.2 & $\mathbf{3}$ \\
\hline $\boldsymbol{- i n g}$ & 81.1 & $\mathbf{2}$ & 84.3 & $\mathbf{2}$ \\
\hline past regular (-ed) & 41.2 & $\mathbf{7}$ & 44.9 & 7 \\
\hline past irregular & 54.9 & $\mathbf{5}$ & 60.6 & $\mathbf{5}$ \\
\hline auxiliary verb bave & & & & \\
\hline past participle (-en) & & & 31.8 & $\mathbf{8}$ \\
\hline be (am, are, $\boldsymbol{i s})$ & 97.8 & $\mathbf{1}$ & 98.3 & $\mathbf{1}$ \\
\hline be (was, were) & 67.1 & $\mathbf{4}$ & 72.9 & $\mathbf{4}$ \\
\hline
\end{tabular}

$\mathrm{r}_{\mathrm{gss}, \mathrm{gm}} 7=1 ; \mathrm{p}<.05, \mathrm{p}<.01$ 
As the results in Table 4 illustrate, the highest accuracy score in Grade 7 was attained for the present tense copula be $(98.3 \%)$, thus ranking this morpheme first. The progressive (-ing) was placed second since it was used accurately $84.3 \%$ of the time. This morpheme was acquired earlier than the auxiliary verb be, which generated a slightly lower accuracy score, differing from the progressive by only $4.1 \%$. Observing the table above, it can be noticed that the past tense copula be is fourth (72.9\%), whereas the past irregular is fifth in rank (60.6\%). Furthermore, the past irregular was acquired earlier (in fifth position) than the past regular (in the seventh position). The past participle (-en) was ranked in the last position with only a $31.8 \%$ accuracy score. Finally, the resulting sequence for Grade 7 pupils is: present tense copula be, progressive (ing), auxiliary verb be, past tense copula be, past irregular, third person singular $(-s)$, past regular and past participle $(-e n)$.

TABLE 5. Order of acquisition of grammatical morphemes in Grade 8.

\begin{tabular}{|l|c|c|c|c|}
\hline $\begin{array}{l}\text { Grammatical } \\
\text { Morpheme }\end{array}$ & $\begin{array}{c}\text { Group } \\
\text { means } \\
\text { method } \\
(\%)\end{array}$ & Rank & $\begin{array}{c}\text { Group } \\
\text { score } \\
\text { method } \\
(\%)\end{array}$ & Rank \\
\hline$-\boldsymbol{s}$ & & & 37.0 & 5 \\
\hline auxiliary verb be & & & & \\
\hline -ing & 47.0 & $\mathbf{4}$ & 49.1 & $\mathbf{4}$ \\
\hline past regular (-ed) & 59.4 & $\mathbf{3}$ & 61.7 & $\mathbf{3}$ \\
\hline past irregular & & & & \\
\hline auxiliary verb have & & & & $\mathbf{1}$ \\
\hline past participle (-en) & 100.0 & $\mathbf{1}$ & 100.0 & $\mathbf{2}$ \\
\hline be (am, are, $\boldsymbol{i s})$ & 83.2 & $\mathbf{2}$ & 81.9 & \\
\hline be (was, were) & & & & \\
\hline
\end{tabular}

$\mathrm{r}_{\mathrm{gs}, \mathrm{gm}} 8=1 ; \mathrm{p}<.05, \mathrm{p}<.01$

The findings presented in Table 5 only partly reveal the rank order of grammatical morphemes in Grade 8, due to their insufficient suppliance. As can be noted, the highest accuracy scores were obtained for two morphemes, the present tense copula be $(100 \%)$ and the past tense copula be $(81.9 \%)$, giving these morphemes the first and second position in the rank order. The rank order for the past regular and the past irregular in Grade 8 seems to follow the same pattern of acquisition as in Grade 6 and Grade 7. Specifically, it appears that the acquisition of the past irregular precedes the acquisition of the past regular, since Grade 8 pupils achieved a higher accuracy score for the past irregular $(61.7 \%)$ than the accuracy score achieved for the past regular (49.1\%). The lowest level of accuracy was found for the third person singular $(-s)(37 \%)$. In sum, the sequence of acquisition by Grade 8 pupils is as follows: present tense copula be, past tense copula be, past irregular, past regular and third person singular $(-s)$.

As in the case of morphemes, the acquisition sequences of verb tenses were observed in each year of learning (Grade 6, Grade 7 and Grade 8). The results are presented here. 
TABLE 6. Order of acquisition of verb tenses in Grade 6.

\begin{tabular}{|l|c|c|}
\hline Method / Rank & $\begin{array}{c}\text { Group score method } \\
(\%)\end{array}$ & Rank \\
\hline Tense & 74.3 & $\mathbf{2}$ \\
\hline Simple present & 76.6 & $\mathbf{1}$ \\
\hline Present continuous & 64.8 & $\mathbf{3}$ \\
\hline Simple past & & \\
\hline Present perfect & & \\
\hline
\end{tabular}

The data in Table 6 indicate that the present continuous is the first acquired tense due to the highest percentage of its accuracy score $(76.6 \%)$. The simple present was positioned second with a slightly lower accuracy score $(74.3 \%)$, whereas the simple past was the last acquired tense. Thus, the acquisition sequence identified by Grade 6 pupils shows the following order: present continuous, simple present and simple past.

TABLE 7. Order of acquisition of verb tenses in Grade 7.

\begin{tabular}{|l|c|c|}
\hline Method / Rank & $\begin{array}{c}\text { Group score method } \\
(\%)\end{array}$ & Rank \\
\hline Sense & 89.1 & $\mathbf{1}$ \\
\hline Simple present & 82.2 & $\mathbf{2}$ \\
\hline Simple past continuous & 60.2 & $\mathbf{3}$ \\
\hline Present perfect & & \\
\hline
\end{tabular}

The ranking results displayed in Table 7 indicate a decrease from the $89.1 \%$ accuracy score attained for the simple present to the $82.2 \%$ accuracy score for the present continuous. The data also point to a much higher decrease in the level of accuracy obtained for the simple past (60.2\%) in comparison to the simple present and the present continuous. Based on these findings, the acquisition sequence by Grade 7 pupils is the following: simple present, present continuous and simple past.

TABLE 8. Order of acquisition of verb tenses in Grade 8.

\begin{tabular}{|l|c|c|}
\hline Method / Rank & $\begin{array}{c}\text { Group score method } \\
(\%)\end{array}$ & Rank \\
\hline Sense & & $\mathbf{1}$ \\
\hline Simple present & 85.5 & $\mathbf{2}$ \\
\hline Simple past continuous & 66.6 & \\
\hline Present perfect & & \\
\hline
\end{tabular}


From Table 8 it can be seen that the ranking order in Grade 8 was identified in the acquisition of only two verb tenses: the simple present and the simple past. An accuracy score of $85.5 \%$ gave the first position to the simple present, while the simple past was ranked second due to a lower accuracy score of almost $20 \%$. As presented in the above table, it can be stated that the simple present emerges before the simple past in the interlanguage of Grade 8 pupils.

Correlations between the acquisition sequences of grammatical morphemes obtained by both methods across Grade 6, Grade 7 and Grade 8 are reported under each table. These results indicate remarkably high correlations reaching statistical significance at the .01 level $(r=0.96$ in Grade 6; $r=1$ in both Grade 7 and Grade 8). Furthermore, there was a significant correlation between acquisition sequences obtained by the group score method in Grade 6 and Grade 7 at the .05 level $(\mathrm{r}=0.79)$ and in Grade 6 and Grade 8 at the .01 level $(\mathrm{r}=1)$. Also, acquisition sequences in Grade 7 and Grade 8 correlated significantly at the .05 level $(r=0.9)$. According to these findings, it can be stated that Grade 6, Grade 7 and Grade 8 pupils exhibit relatively similar acquisition sequences of morphemes. Since acquisition sequences were detected for just two or three verb tenses, the Spearman rank correlation coefficients for the same group of pupils over the three years of learning could not be computed.

\subsection{Results on Improvement in the Acquisition of Grammatical Morphemes and Verb Tenses}

This subsection presents the results resolving RQ3. The grammatical morphemes for which average accuracy scores could be calculated include the present tense copula $b e$, the past tense copula $b e$, the past regular and the past irregular. The differences in the acquisition of the present tense copula be across Grade 6, Grade 7 and Grade 8 (Table 9) reached statistical significance at the .05 level $\left(\chi^{2}=8.667 ; \mathrm{df}=2 ; \mathrm{p}<.05\right)$. Moreover, it is the only statistically significant difference despite the appearance of relatively similar average accuracy scores in Grade $6(98.8 \%)$ and Grade 7 (97.8\%), undergoing an increase to $100 \%$ in Grade 8. It appears that this seemingly non-existent variability in the accuracy score made these differences statistically significant.

TABLE 9. Average accuracy score/differences in acquisition for the copula be (am, are, is) across Grade 6, Grade 7 and Grade 8.

\begin{tabular}{|c|c|c|c|c|c|c|c|}
\hline $\begin{array}{c}\text { Grammatical } \\
\text { morpheme }\end{array}$ & Grade & $\begin{array}{c}\text { Number } \\
\text { of pupils } \\
(\mathrm{N})\end{array}$ & $\begin{array}{c}\text { Average } \\
\text { accuracy } \\
\text { score }(\%) \\
\end{array}$ & $\begin{array}{l}\text { Standard } \\
\text { deviation }\end{array}$ & Minimum & Maximum & \multirow{4}{*}{$\begin{array}{c}\chi 2=8.667 ; \\
\text { df }=2 ; \\
\text { p }<.05\end{array}$} \\
\hline \multirow{3}{*}{$\begin{array}{l}\text { be } \\
(\text { am, are, is })\end{array}$} & 6 & 10 & 98.8 & 1.98 & 95.50 & 100.00 & \\
\hline & 7 & 10 & 97.8 & 2.52 & 93.30 & 100.00 & \\
\hline & 8 & 10 & 100 & .00 & 100.00 & 100.00 & \\
\hline
\end{tabular}

Furthermore, it appears that there are no statistically significant differences in both the acquisition of the past tense copula be $\left(\chi^{2}=3.467 ; \mathrm{df}=2 ; \mathrm{p}>.05\right)$ and the past regular $\left(\chi^{2}=2.741 ; \mathrm{df}=2 ; \mathrm{p}>.05\right)$ across Grade 6, Grade 7 and Grade 8. As for the past irregular, the differences in its acquisition over the same period were not found to be significant. 
TABLE 10. Average accuracy scores for $-s$, the auxiliary verb be and -ing for Grade 6 and Grade 7.

\begin{tabular}{|l|c|c|c|c|c|c|}
\hline $\begin{array}{c}\text { Grammatical } \\
\text { morpheme }\end{array}$ & Grade & $\begin{array}{c}\text { Number } \\
\text { of pupils } \\
(\mathrm{N})\end{array}$ & $\begin{array}{c}\text { Average } \\
\text { accuracy } \\
\text { score } \\
(\%)\end{array}$ & $\begin{array}{c}\text { Standard } \\
\text { deviation }\end{array}$ & Minimum & Maximum \\
\hline$-s$ & 6 & 17 & 45.3 & 24.92 & .00 & 81.50 \\
\hline aux. verb be & 6 & 18 & 63.2 & 36.22 & .00 & 100.00 \\
\hline- ing & 6 & 18 & 79.5 & 19.88 & 33.30 & 100.00 \\
\hline$-s$ & 7 & 12 & 39.5 & 31.57 & .00 & 83.30 \\
\hline aux. verb be & 7 & 13 & 73.1 & 23.67 & 25.00 & 100.00 \\
\hline- ing & 7 & 13 & 81.1 & 24.09 & 25.00 & 100.00 \\
\hline
\end{tabular}

Regarding Table 10, it can be noted that the use of $-s$ leads to a decrease in the average accuracy score between Grade 6 (45.3\%) and Grade 7 (39.5\%). However, an increase in the average accuracy score for the auxiliary verb be and the progressive (-ing) is evidenced between Grade 6 and Grade 7. Nevertheless, there are no statistically significant differences in both the acquisition of the auxiliary verb be and the progressive, as well as in the acquisition of $-s$ between the two years of learning.

The average accuracy scores, alongside the significance of differences in the acquisition of verb tenses across Grade 6, Grade 7 and Grade 8, could be calculated for the simple present and the simple past. Differences in the acquisition of the simple present across the three years of learning do not indicate any statistical significance $\left(\chi^{2}=2.714 ; \mathrm{df}=2 ; \mathrm{p}>.05\right)$. Also, the acquisition of the simple past did not reveal any differences reaching statistical significance over the same period of learning. Similar results with regard to the significance of differences in the acquisition of the present continuous between Grade 6 and Grade 7 were found. Although the average accuracy score for the present continuous underwent an increase from $70.5 \%$ to $80.2 \%$, no significant statistical differences were shown in its acquisition.

\subsection{Results on the Acquisition of the Past Regular and the Past Irregular}

The findings presented hereafter answer RQ4. The results from Table 2 indicate that pupils across Grade 6, Grade 7 and Grade 8 always more often correctly supplied the past irregular in comparison to the past regular. Grade 6 pupils used the past irregular $9 \%$ more correctly than they used the past regular, whereas Grade 7 pupils used it 14\% more correctly. This higher percentage of correct suppliance in the use of the past irregular as opposed to the past regular was as much as $10 \%$ higher in Grade 8 when compared to Grade 7 . According to the rank order results (Table 3, Table 4 and Table 5) it is evident that pupils across Grade 6, Grade 7 and Grade 8 always provided higher accuracy scores for the past irregular than for the past regular.

\subsection{Results on the Acquisition of Compound Verb Tenses}

In view of the acquisition of compound tenses (RQ5) starting with the present continuous, it is remarkable that both Grade 6 and Grade 7 pupils showed more correct use of the verbal suffix in 
relation to the correct use of the auxiliary verb be, even though the correct suppliance between these morphemes varied by only $1 \%$ in Grade 7 and by 2\% in Grade 6 (Table 2). Regarding the same tense, it can be further noted that the progressive -ing tends to occupy a higher position in the rank order in both Grade 6 (Table 3) and Grade 7 (Table 4) due to its higher accuracy score when compared to the auxiliary verb be. As for the present perfect, the acquisition of this tense could not be investigated at all.

\section{Discussion}

The final part of this paper discusses the research results. The discussion is conducted following the research questions.

\subsection{Suppliance and Distribution of Grammatical Morphemes regarding Their Obligatory and Correct Use}

As mentioned in section 5.1, the unequal distribution of morphemes may be attributed to the type of communicative activity. On the one hand, some of the designed activities were not applied at all in this study. For instance, a questionnaire designed to elicit the use of the auxiliary verb have and the past participle was not applied in Grade 8 due to the pupils' refusal. On the other hand, task-based activities differed in the amount of morphemes supplied during speech production. For example, role-plays provided a wider range of morphemes when compared to other types of activity, such as starting with the same question and thus eliciting the same morpheme. It should be further pointed out that the duration of communicative activities might have affected the distribution of the grammatical morphemes under study. Despite the approximately 15-minute time frame, the flow of the activities was not interrupted until reaching a communicative goal, which resulted in more obligatory use for some of the morphemes.

One of the reasons for the lack in the suppliance of morphemes in the use of not only the present perfect, as previously indicated, but also in the use of the present continuous in Grade 8, can be found among the pupils. In situations where Grade 8 pupils were not motivated enough to participate in a predetermined communicative activity, they were given the opportunity to select another type of task-based activity due to their entirely voluntary participation. Furthermore, the number of pupils engaged in speech production seems to have an impact on the distribution of morphemes. It can be noted that the number of pupils involved in the target language production varied, which resulted in an uneven suppliance of grammatical morphemes over the three-year period.

\subsection{Acquisition Orders of Grammatical Morphemes and Verb Tenses}

When comparing morpheme orders (Table 3, Table 4 and Table 5), it can be observed that the rank order could not be determined for the morphemes constituting the present continuous (Table 5) and the present perfect (Table 3 and Table 5) due to, as previously explained, the lack of their suppliance. As for the past participle (Table 4), its position in the rank order could be ignored for several reasons. First, the acquisition of this morpheme was not intended to be investigated separately but along with the acquisition of the auxiliary verb have, since both constitute the present perfect. Second, it is positioned last in the rank order and third, it is most probably, as noted before, a case of incorrect coding. 
The comparison of acquisition orders (Table 6, Table 7 and Table 8) indicates that some of the features regarding tense acquisition in Grade 7 are present in both Grade 6 and Grade 8 . Specifically, the simple past seems to emerge last not only in Grade 7 but also in Grade 6. Also, it seems that the simple present is the first tense to emerge in Grade 7 and the following year in Grade 8 .

It is interesting to point out that the results regarding acquisition orders showed that higher levels of correct suppliance in the use of either morphemes or verb tenses is not a necessary prerequisite for their earlier acquisition. As for morphemes, it appears that more frequent correct suppliance as a prerequisite for earlier acquisition can be found in Grade 6 and Grade 7 but not in Grade 8 . On the one hand, the findings have revealed that Grade 6 and Grade 7 pupils most frequently correctly supplied the present tense copula be which, by being positioned first in the rank order, seems to be acquired first. On the other hand, Grade 8 pupils seem to acquire the past irregular somewhat later since this morpheme, despite displaying the highest levels of correct suppliance, was ranked third. As for verb tenses, similar results have been found. While Grade 7 pupils showed the greatest level of correct suppliance for the simple present, which accordingly took the first position in the rank order, Grade 6 and Grade 8 pupils revealed the opposite. Despite the highest frequency of correct suppliance for the simple present in Grade 6 and the simple past in Grade 8, the two tenses were positioned second.

\subsection{Improvement in the Acquisition of Grammatical Morphemes and Verb Tenses}

Even though there were no statistically significant differences in the acquisition of the past tense copula be and the past regular, the obtained results should be cautiously interpreted rather than suggesting no improvement in the acquisition of these morphemes over the three-year period due to the relatively small number of pupils in the sample $(\mathrm{N}=8$ for the past tense copula $b e, \mathrm{~N}=7$ for the past regular). Furthermore, an increase in the average score for both the auxiliary verb be and the progressive (-ing) is supported by the previous rank order results. These results indicate an improvement from the fourth position in Grade 6 (Table 3) to the third position in Grade 7 (Table 4) for the auxiliary verb be, whereas the progressive changed from the third rank order position in Grade 6 (Table 3) to the second position in Grade 7 (Table 4).

\subsection{Acquisition of the Past Regular and the Past Irregular}

The obtained findings strongly suggest that pupils across Grade 6, Grade 7 and Grade 8 acquire the past irregular prior to the past regular. This claim is supported by both the results on the suppliance of grammatical morphemes and the rank order results.

\subsection{Acquisition of Compound Verb Tenses}

The acquisition of the present continuous could not be investigated in Grade 8 due to, as already mentioned, no suppliance in the use of its constituent elements, thus resulting in no ranking order for these morphemes. For the same reason, the acquisition of the present perfect could not be investigated despite the data displaying occurrences of the use of the past participle ( $-e n)$ in Grade 7 since, as specified before, this might be the case of incorrect coding. 


\section{Conclusions}

The aim of this study is to shed more light on the acquisition of verbal morphology in the interlanguage of Croatian L2 pupils of English. Research into grammatical development was based on the orders of acquisition of grammatical morphemes and verb tenses with special emphasis on the principles of tense-aspect acquisition (Bardovi-Harlig 2000). The findings of the study pointed to several conclusions.

The suppliance of grammatical morphemes seems to be related to both the type of communicative activity and the pupils. On the one hand, more frequent use of a particular task-based activity might provide more obligatory and thus possibly more correct use in morpheme suppliance. Based on the findings, it may be concluded that the range of morphemes in the pupils' target language production depends on the type of communicative activity. Some activities provide a wider use of morphemes, unlike some other activities which focus on the use of only specific morphemes. Therefore, the impact of a task-based activity type on morpheme suppliance should be further investigated. On the other hand, the frequency in the use of communicative activities varied across Grade 6, Grade 7 and Grade 8 due to pupils' preferences. Since this study was based on the pupils's voluntary participation, future research regarding the influence of affective factors (e.g., motivation, attitude towards foreign language learning) should also be undertaken.

Although the research design in this study was modified, it can be concluded that Croatian L2 pupils of English demonstrate homogeneity in the sequences of acquisition of grammatical morphemes across Grade 6, Grade 7 and Grade 8, as indicated by the Spearman rank order correlations. However, since the grammatical morphemes exhibit slightly different ranking orders when their acquisition in each year of learning is observed separately, it can be further concluded that the universality of acquisition sequences can only be justified from the statistical point of view, as claimed by Luk and Shirai (2009). In addition, the less than clear insight into the acquisition sequences of compound verb tenses necessitates further research not only into the compound tenses but also into some other compound tenses (e.g., past continuous). In addition, the research should be further extended to include the acquisition of verbal morphology, with temporal reference viewed separately (present vs. past).

The findings obtained by this research, although showing significant differences only in the acquisition of the present tense copula be across Grade 6, Grade 7 and Grade 8, do not necessarily lead to the conclusion that there was no evidence of morphological improvement, but rather imply that it was somewhat more difficult to identify it over the three-year period of learning. It seems that the length of this longitudinal study should therefore be extended to a much longer period. Also, the relatively small number of pupils participating in this study might have led to less evident improvement in the acquisition of both grammatical morphemes and verb tenses. Further research should hence be conducted as a case study, thus focusing on a few pupils, which might presumably lead toward more explicit evidence of grammatical improvement.

The results showing that irregular morphology precedes regular morphology point to the conclusion that Croatian L2 pupils of English acquire verbal morphology according to the third principle (Bardovi-Harlig 2000). Although inconclusive, the results also indicate that Grade 6 and Grade 7 pupils acquire the verbal suffix first and only subsequently the auxiliary verb, thus following the fourth principle (Bardovi-Harlig 2000). It can be further concluded, based on the overall findings which reveal the slow and gradual acquisition of both grammatical morphemes and verb tenses, that pupils across Grade 6, Grade 7 and Grade 8 follow the first principle of tense-aspect acquisition (Bardovi-Harlig 2000). 


\section{References}

Ajduković, Marina, and Vladimir Kolesarić, eds. 2003. Ethical Code for Research with Children. Zagreb: Croatian Government's Council for Children. State Office for the Protection Family, Maternity and Youth.

Bailey, Nathaline, Carolyn Madden, and Stephen Krashen. 1974. "Is There a "Natural Sequence" in Adult Second Language Learning?” Language Learning 1: 235-43. doi:10.1111/j.1467-1770.1974.tb00505.x.

Bardovi-Harlig, Kathleen. 1997. "Another Piece of the Puzzle: The Emergence of the Present Perfect." Language Learning 47 (3): 375-422. doi:10.1111/0023-8333.00015.

-. 2000. Tense and Aspect in Second Language Acquisition: Form, Meaning and Use. Oxford: Oxford University Press.

Billings, Marion. 1999. "Greedy to Know English: A Case Study.” Master's thesis, University of Regina.

Brown, Roger. 1973. A First Language. Harvard: Harvard University Press.

Cook, Vivian. 1993. Linguistics and Second Language Acquisition. New York: St. Martin’s Press.

Council of Europe. 2001. Common European Framework of Reference for Languages: Learning, Teaching, Assessment. Cambridge: Cambridge University Press.

Ministry of Science and Education of the Republic of Croatia. 2011. Croatian National Curriculum. http:// public.mzos.hr/Default.aspx?sec=2501.

DuBois, John W. 1991. “Transcription Design Principles for Spoken Discourse Research.” Pragmatics 1 (1): 71-106. doi:10.1075/prag.1.1.04boi.

Dulay, Heidi C., and Martina K. Burt. 1973. “Should We Teach Children Syntax?” Language Learning 23 (2): 245-58. doi:10.1111/j.1467-1770.1973.tb00659.x.

—. 1974. "Natural Sequences in Child Second Language Acquisition." Language Learning 24 (1): 37-53. doi:10.1111/j.1467-1770.1974.tb00234.x.

—. 1980. "On Acquisition Orders." In Second Language Development: Trends and Issues, edited by Sascha W. Felix, 265-328. Tübingen: GunterNarr.

Edwards, Jane A. 2001. “The Transcription of Discourse.” In The Handbook of Discourse Analysis, edited by Deborah Schiffrin, Deborah Tannen and Heidi E. Hamilton, 321-48. Malden, MA: Blackwell.

Edwards, Jane A., and Martin D. Lampert, eds. 1993. Talking Data: Transcription and Coding in Discourse Research. Hillsdale, NJ: Lawrence Erlbaum.

Ellis, Rod. 2008. The Study of Second Language Acquisition. Oxford: Oxford University Press.

Ellis, Rod, and Gary Barkhuizen. 2005. Analysing Learner Language. Oxford: Oxford University Press.

Hakuta, Kenji. 1974. "A Preliminary Report on the Development of Grammatical Morphemes in a Japanese Girl Learning English as a Second Language." Working Papers in Bilingualism 3: 18-43.

Harmer, Jeremy. 1999. The Practice of English Language Teaching. London: Longman.

Lakshmanan, Usha, and Larry Selinker. 2001. "Analysing Interlanguage: How do We Know What Learners Know?” Second Language Research 17 (4): 393-420. doi:10.1177/026765830101700406.

Larsen-Freeman, Diane. 1975. "The Acquisition of Grammatical Morphemes by Adult Learners of English as a Second Language.” PhD diss., University of Michigan.

Long, Michael, and Charlene Sato. 1984. "Methodological Issues in Interlanguage Studies: An Interactionist Perspective." In Interlanguage, edited by Alan Davies, Clive Criper and A. P. R. Howatt, 253-80.

Edinburgh: Edinburgh University Press. 
Luk, Zoe Pei-sui, and Yasuhiro Shirai. 2009. "Is the Acquisition Order of Grammatical Morphemes Impervious to L1 Knowledge? Evidence from the Acquisition of Plural -s, Articles, and Possessive's." Language Learning 59 (4): 721-54. doi:10.1111/j.1467-9922.2009.00524.x.

Makino, Taka-Yoshi. 1980. "Acquisition Order of English Morphemes by Japanese Secondary School Students." Journal of Hokkaido University of Education 30 (2): 101-48.

Ortega, Lourdes. 2009. Understanding Second Language Acquisition. London: Hodder Education.

Pak, Yunhwa. 1987. "Age Difference in Morpheme Acquisition among Korean EFL Learners: Acquisition Order and Acquisition Rate." PhD diss., University of Texas, Austin.

Pica, Teresa. 1983. "Adult Acquisition of English as a Second Language under Different Conditions of Exposure.” Language Learning 33: 465-97. doi:10.1111/j.1467-1770.1983.tb00945.x.

Thornbury, Scott. 2005. How to Teach Speaking. Harlow, England: Longman.

Ur, Penny. 1999. A Course in Language Teaching: Practice and Theory. Cambridge: Cambridge University Press.

Wang, Li. 2000. “Acquisition of Grammatical Morphemes: A Case Study of Lan.” Master's thesis, University of Regina. 